\title{
GENDER AND VICTIMIZATION IN MARGARET ATWOOD'S SURFACING
}

\author{
Álvaro Pina Arrabal
}

Universidad de Jaén

\begin{abstract}
Margaret Atwood's Surfacing (1972), a contemporary classic nowadays, has raised the interest of all kinds of critics. Some of the most remarkable elements in the novel concern feminism, a movement with which the Canadian author has been highly committed. This paper deals with two specific aspects in Atwood's work in relation to the aforementioned critical approach: gender and victimization. A thorough reading of the novel is thus done in order to detect and subsequently dissect the main instances of both aspects. Special attention is paid to female characters (Anna and the unnamed protagonist), hypersexualized and victimized in the patriarchal microcosms rendered in the story.
\end{abstract}

Keywords: Atwood, feminism, gender, victimization, hypersexualization, patriarchy

\section{Resumen}

Surfacing (1972), de Margaret Atwood, un clásico contemporáneo hoy en día, ha despertado el interés de todo tipo de críticos. Algunos de los elementos más destacables de la novela atañen al feminismo, un movimiento con el que la autora canadiense ha tenido un gran compromiso. Este trabajo aborda dos aspectos específicos en la obra de Atwood en relación con el mencionado enfoque crítico: género y victimización. Se hace así una lectura exhaustiva de la novela a fin de detectar y analizar minuciosamente los principales ejemplos de uno y otro aspecto. Se presta especial atención a los personajes femeninos (Anna y la protagonista sin nombre), hipersexualizadas y victimizadas en el microcosmos patriarcal que se representa en la historia.

Palabras clave: Atwood, feminismo, género, victimización, hipersexualización, patriarcado 


\section{Introduction}

Surfacing (1972) is the second novel by the Canadian writer Margaret Atwood. It narrates the story of an unnamed woman who goes, with her boyfriend Joe and another couple (David and Anna), to her homeland in Canada (Northern Quebec) to investigate the mysterious disappearance of her father, of which she has been informed through a letter sent by Paul, a friend from the place. What follows is a journey of self-discovery: the unnamed protagonist (UP hereafter, for mere communicative pragmatism) immerses herself in a process of remembrance through which her past and present intertwine.

Whereas in the book Atwood reflects upon a variety of topics (identity, language, memory, imagination and hallucination or human and animal life, to mention but a few of them), this paper will be exclusively focused on gender issues, certainly one of the fundamental aspects in the construction of the novel. In particular, special attention will be paid to the sense of victimization on the part of the two female characters of the story: UP and Anna, different women that are somehow connected in the plot because of their female condition.

Since a close reading of the novel has been done to write this essay, passages from the book will be frequently quoted in order to illustrate the ideas covered; this will be the main point of reference for the elaboration of the work. In a complementary way, we will also occasionally include some specific academic references that may corroborate our thesis or, simply, add relevant information to the topic of the paper. Specifically, the main bibliographical sources used belong to the gender studies field and offer a feminist approach to Atwood's novel, with special emphasis on the notion of victimization and on its relation with nature that is, ecofeminism - through the characters and elements shaping the work.

In this way, the current article intends to revise such aspects and expand on them by doing, as stated by New Criticism, a close reading of the text. This is precisely where the originality of our paper may mostly lie. When the fragments quoted correspond to Atwood's book, we will simply specify between brackets the number of the page(s) from which each quotation has been extracted.

\section{Preliminary notes on gender issues in the novel}

The course of events in Surfacing is intelligently unfolded by Margaret Atwood in such a way that the sense of female subalternity (adapting Antonio Gramsci's [2005] wider term) is gradually perceived in a more conspicuous manner. Already at the beginning of chapter 1, UP is in David's car ("a lumbering monster," [4] as she labels it) on her way to Quebec and remarks: "David says 
they can't afford a newer one, which probably isn't true. He's a good driver, I realize that, I keep my outside hand on the door in spite of it" (4). At this early point of the story, readers may wonder if they are reading the words of an overly dubious narrator or those of a victimized woman in a precarious position; throughout the novel we notice it is the latter.

Needless to say, to reach such conclusion we have to rely on the perception of an unnamed narrator who seems to suffer from hallucination. Although we consider that her voice is perfectly reliable regarding the description of factual events (past and present) and we will develop our thesis accordingly, we anyway believe that mentioning it is not pointless: the novel is written in first-person, which inevitably entails a series of specificities and narrative limitations. Reductio ad absurdum or not, the reader is never told explicitly that UP is a woman; synopsis in the back cover of the book aside, we must infer it from the way she interacts with the other characters and from some particularly clarifying reflections on marriage, school life or men's tastes, such as: "My status is a problem, they obviously think I'm married. But I'm safe, I'm wearing my ring, I never threw it out, it's useful for landladies" (24); "it was worse for a girl to ask questions than for a boy" (124); "men's magazines were about pleasure, cars and women" (143). By extension, it also seems quite congruent that the book is the work of a female writer; would a man have been able to convey the same feelings of the protagonist in the way Margaret Atwood does? ${ }^{1}$

Evidently enough, the fact that the protagonist is a woman is paramount in shaping the narrative mood of the novel and its subsequent feminist interpretations: the whole story is filtered through her perception of reality as a woman. To give but one example, if the story were narrated by David, the scene in which Anna is forced to take off her clothes would obviously still be an abuse, but it would, however, be probably approached as 'mere fun' -or similar- on the part of the narrator. In other words, whereas facts in the story remain the same regardless of the narrating voice, the process of filtering and analyzing them for a feminist study such as this is different and, probably, shorter when we are told the

\footnotetext{
${ }^{1}$ Most likely, cross gender writing requires a higher degree of reason and objectivity on the part of writers, who cannot transfigure their own experiences in their fictional alter ego in the way they would do with a character of their same sex. As psychologist Dr. Vivian Diller (quoted in Willens) explains, "Authors who write about their own gender use their internal experience and speak from the inside out. When they write about the opposite sex, their perspective has to shiftfrom the outside in. Neither is necessarily better but rather they try different points of view." This obviously does not necessarily mean that a female author cannot shape a complex male character or vice versa (Gustave Flaubert's Madame Bovary [1857] or León Tolstói's Anna Karénina [1877] are two eloquent instances of it); it simply is, in any case, a worth considering tendency.
} 
story by a female character. The voices of both the first-person narrator and of Margaret Atwood herself strengthen and facilitate dealing with the book from a female perspective.

Notwithstanding that a biographical reading of the novel is not our main aim, we consider it pertinent to mention here that the thoughts and insight of the author and the protagonist may intertwine in more than one occasion. ${ }^{2}$ One year after the publication of Surfacing, in 1973, Margaret Atwood divorced from her first husband; the novel -maybe as a correlative fiction- is brimming with reflections on marriage and divorce, two of the elements from the past of the protagonist that linger on her present and that more clearly configure her distress and victim status (which we will explore more deeply in the next section). In chapter 3, UP brings to mind her marriage and divorce for the first time, when thinking of her parents: "they never forgave me, they didn't understand the divorce; I don't think they even understood the marriage, which wasn't surprising since I didn't understand it myself" (32). Later on, she remembers her ex-husband from the point of view of failure: "It was good at first but he changed after I married him, he married me, we committed that paper act" (46). Concurrently, a sentiment of forced pregnancy is noticeable in her words: "It was my husband's [child], he imposed it on me, all the time it was growing in me I felt like an incubator" (38-39); or "He wanted a child, that's normal, he wanted us to be married" (56). In other cases, the wedding ring is even depicted as a symbol of oppression: "I wore his ring, too big for any of my fingers, around my neck on a chain, like a crucifix or a military decoration" (62). All these somehow repressed feelings will derive in the character's reluctance to become engaged again, which will trigger the arguments between her and Joe in the second part of the novel. The following passage illustrates how her former marriage still haunts her in a powerful way:

'Look', I said, 'I've been married before and it didn't work out. I had a baby too'. My ace, voice patient. 'I don't want to go through that again.' It was true, but the words were coming out of me like the mechanical words from a talking doll, the kind with the pull tape at the back; the whole speech was unwinding, everything in order, a spool. I would always be able to say what I'd just finished saying: I've tried and failed, I'm inoculated, exempt, classified as wounded. It wasn't that I didn't

\footnotetext{
${ }^{2}$ Although any literary work is somehow autobiographical, it is no less true that in some cases the sense of autobiography is much more conspicuous or significant than in others. In Surfacing, we mean that some of Atwood's ideas and logical processes can be particularly relevant to understand those of UP and, perhaps to a lesser extent, of Anna and even of the rest of the characters. The author dilutes her consciousness among the different actants -following Greimas' terminology-, but only one or two of them are imbued with the greatest part of it.
} 
suffer, I was conscientious about that, that's what qualified me. But marriage was like playing Monopoly or doing crossword puzzles, either your mind worked that way, like Anna's, or it didn't; and I'd proved mine didn't. A small neutral country. (110-11)

The ideas about marriage and giving birth appear throughout the whole novel and, especially, in the first part, where we find one of Atwood's most famous quotations: "A divorce is like an amputation, you survive but there's less of you" (49). Judging by the author's own sentimental situation when writing the book, it should thus be no surprise that, albeit not exactly an alter ego, UP is used by Atwood to channel some of her own thoughts, perhaps particularly intense at that time. Critics have indeed celebrated Surfacing, as Fiona Tolan (35) notes, "as the work that most closely associates Atwood's novel writing to her poetry." The writer being a woman is definitely an important aspect to be taken into consideration when analyzing the feminist framework of the novel.

\section{Victimization in female characters}

As it has been already remarked, there is more than one element conveying a sense of victimization in Surfacing; namely, the American pervasive politics and way of life (specifically, affecting nature and Canadian identity) and the dominance of an overly patriarchal culture. In this regard, Emily Denommé (2) alludes to a double sense of victimization: "The journey of Atwood's narrator highlights the problematic groupings that her society demands in terms of nationality and gender. Under these categories, the narrator is doubly victimized as a Canadian and as a woman". While it is convenient to have the former in mind too, we will henceforth refer almost exclusively to the latter: victimization of women as the result of masculine dominance.

The sense of gender victimization in the novel is, in turn, split between the two main female characters of the story, Anna and UP (the two other women characters being Madame -Paul's wife- and a random clerk from a store, both of whom appear only in the first chapters). Interestingly enough, although both of them are arguably victims of patriarchal society in general and of their respective relationships with males in particular, their attitudes towards the situation differ significantly: whereas Anna seems to accept her position willingly and gives a rather submissive image of herself in certain moments, UP is distraught by gender problems since her childhood (at school and even with family) and is unable to engage with Joe because of it. This being the case, we have opted for analyzing the role of each of them by separate for the sake of clarity. 


\subsection{Anna}

In the same way the story unfolds gradually, the actual victim role of Anna in relation to her husband, David, is discovered throughout the chapters. Margaret Atwood is, again, very skillful in revealing it in a gradual manner. At the beginning, the reader may easily get the impression that they make a happy and healthy couple, but, nothing further from the truth, Anna undoubtedly suffers abuse at the hands of her husband. One of the first instances is found in chapter 4, when David asks someone to bring him a beer and "Anna brings him one and he pats her on the rear and says "That's what I like, service" (41). At this point, it is already surprising that she does it automatically, as though she were a robot at his beck and call; all the same, the abuse goes in crescendo.

In the next chapter, UP sees Anna putting on makeup and realizes that she has never seen her without it. When asked about the reason by the narrator, "Anna says in a low voice, 'He doesn't like to see me without it"', and then, contradicting herself, "He doesn't know I wear it" (52). Later on, there is a scene in which Anna has forgotten to make herself up, and converse with the protagonist as follows:

"God," she said, "what'm I going to do? I forgot my makeup, he'll kill me."

I studied her: in the twilight her face was grey. "Maybe he won't notice," I said.

"He'll notice, don't you worry. Not now maybe, it hasn't all rubbed off, but in the morning. He wants me to look like a young chick all the time, if I don't he gets mad."

... "He watches me all the time, he waits for excuses. Then either he won't screw at all or he slams it in so hard it hurts. I guess it's awful of me to say that" ... "But if you said any of this to him he'd just make funny cracks about it, he says I have a mind like a soap opera, he says I invent it. But I really don't you know" (156)

So deep-rooted is her fear towards David that, after these words, Anna does not want to tell UP anything else, afraid that she "would talk to him about it behind her back" (157). David's blatant disregard for her wife is continuous and evinces his sexist ideology; he makes several commentaries that leaves no room for doubts in this respect, such as “'It turns me on when she bends over,' ... 'She's got a neat ass. I'm really into the whole ass thing. Joe, don't you think she's got a neat ass?"' (114). As might be expected, this behavior evolves into aggression in one of the most shocking passages of the entire novel, in which David asks Anna to take off her clothes in order to record a video -Joe and him are on the trip to record a video 
with their camera- of her completely naked. She logically refuses, but, even despite Joe's dissuasive attitude (“'I won't take her if she doesn't want to', Joe said" [172]), David perseveres and the tense situation explodes:

"It's token resistance," David said, "she wants to, she's an exhibitionist at heart. She likes her lush bod, don't you? Even if she is getting too fat"

"Don't think I don't know what you're trying to do," Anna said, as though she'd guessed a riddle. "You're trying to humiliate me."

"What's humiliating about your body, darling?" David said caressingly. "We all love it, you ashamed of it? That's pretty stingy of you, you should share the wealth; not that you don't."

Anna was furious now, goaded, her voice rose. "Fuck off, you want bloody everything don't you, you can't use that stuff on me."

"Why not," David said evenly "it works. Now just take it off like a good girl or I'll have to take it off for you." (172-73)

When Joe tries to stop the quarrel, David yells "Shut up, she's my wife" (173) and goes on. The situation ends with Anna naked, being recorded on the sand while crying. It is the natural consequence of her lenient and submissive attitude, which has not but strengthened David's chauvinist mentality. Denommé (2016: 67) has accurately explained the reason behind Anna's overtolerance by quoting Atwood's most well-known work of literary criticism, Survival: A Thematic Guide to Canadian Literature:

Anna herself, though clearly a victim of sexist ideology, willingly chooses to back her abuser when she must choose where to position herself. This follows Atwood's logic of the first victim position of denied victimhood, where the victim is "afraid to recognize they are victims for fear of losing the privileges that they possess" and often direct their anger "against one's fellow-victims, particularly those who try to talk about their victimization ["]. (Atwood, Survival 36)

This permissiveness on the part of Anna (in the sense of sexual freedom, as David exemplifies when trying to have intercourse with UP in chapter 18, towards the end of part two) is unmistakably obvious in a conversation between the two female characters, narrated this way by the protagonist: "She gives me an odd glance, as though I've violated a propriety, and I'm puzzled, she told me once you shouldn't define yourself by your job but by who you are. When they ask her what she does she talks about fluidity and Being rather than Doing; though if she doesn't like the person she just says 'I'm David's wife"" (70). If we accept the aforementioned idea that Margaret Atwood hybridizes many of her own thoughts The Grove. Working Papers on English Studies 26 (2019): 89-102. ISSN: 2386-5431. 
about feminism with those of UP -the vehicle through which she, in a sense, indirectly theorizes in Surfacing-, then this passage is to be taken as a paradigmatic example. In her doctoral thesis, Suman Makhaik (147) refers to this fact as follows:

The character of Anna stands for women who, against all odds, wish to continue their victim roles even if it demands their total effacement as individuals. Such characters comply with binary masculine hegemony and help in its firm establishment. Ecofeminists raise a voice against doing so, and Atwood establishes the same by defining the negatives.

Ecofeminism, which is a type of feminist theory linked to ecology, is arguably also in the background in Atwood's novel. We will succinctly comment on this aspect in the next point.

\subsection{The protagonist}

The title of the book -Surfacing- is not meaningless either: the unnamed protagonist, a castaway in the sea of patriarchal society and in her own sea of fractured memories and experiences, goes through a process of self-discovery when investigating the disappearance of her father. This inner journey is metaphorically represented by the natural environment where most of the story takes place and, in particular, by water. In chapter 23 , once she has managed to remain alone in the island, UP steps into the water and floats with her clothes on, which she soon takes off: "When every part of me is wet I take off my clothes, peeling them away from my flesh like wallpaper. They sway beside me, inflated, the sleeves bladders of air" (230). Then, after leaving the water, the metaphor cannot be more explicit: "When I am clean I come up out of the lake, leaving my false body floated on the surface, a cloth decoy; it jiggles in the waves I make, nudges gently against the dock" (231). In order to understand this twofold process of surfacing we must, however, clarify UP's position as a victim first. G. Sankar and R. Soundararajan (41) have indeed observed a strong sense of gender victimization in the character:

The main issue of the novel is that of searching for identity. The unnamed protagonist perceives herself as a victim; ... as a member of patriarchal society, she is a victim of men: not only, in the protagonist's view, do they make use of women's bodies for their own satisfaction, but also have more rights. They are those who have the main voice in creating history and think they are responsible for "saving the world, men think they can do it with guns. (Surfacing 176) 
This victim status of the protagonist, originating from society as an abstract whole, crystallizes in her interpersonal relations with Joe, David and even Anna; the macrocosms in which she feels trapped is concretized, in the novel, in a microcosm where gender discrimination takes shape. As it happened with Anna, the reader may initially believe that UP is making the journey simply because she wants to enjoy herself with her friends and boyfriend. Nevertheless, it is soon discovered that she has no choice: she depends on David's car and she has not told any of them the true reason why she wanted to go to the island (investigating her father disappearance). Even if she wishes to leave the place, she is subject to her friends' will:

I sit down on the bed. They might have asked me first, it's my house. Though maybe they're waiting till I come out, they'll ask then. If I say I don't want to they can't very well stay; but what reason can I give? I can't tell them about my father, betray him; anyway they might think I was making it up. There's my work, but they know I have it with me. I could leave by myself with Evans but I'd only get as far as the village: it's David's car, I'd have to steal the keys, and also, I remind myself, I never learned to drive. (86)

During her sojourn in the place, she is invaded by the memories linked to the objects with which she interacts in the house. It is then that she recalls different points of her life when she has been a victim of machismo and of men's impositions. When she tried to become an artist, her wings were clipped by her ex-husband for being a woman: "For a while I was going to be a real artist; he thought that was cute but misguided, he said I should study something I'd be able to use because there have never been any important woman artists" (63). At school, she was an object of ridicule for the boys: "When the boys chased and captured the girls after school and tied them up with their own skipping ropes, I was the one they would forget on purpose to untie. I spent many afternoons looped to fences and gates and convenient trees, waiting for a benevolent adult to pass and free me" (88). Even with her family, she was conditioned by the manly habits of her father: "There's more than one way to skin a cat, my father used to say; it bothered me, I didn't see why they would want to skin a cat even one way" (117). On top of all these memories, one weighs heavily: the feeling of having lost her child, presumably aborted against her will. We will refer to this point at the end of the analysis of the character.

Considering animal mistreatment (epitomized by the skinned cat) and the defilement of nature by Americans in the novel, the critics have underlined the presence of an ecofeminist message in Atwood's work. In this line, Ambika Bhalla (1) has observed a parallelism between the victim status of the main character and The Grove. Working Papers on English Studies 26 (2019): 89-102. ISSN: 2386-5431. 
nature, which becomes a revealing force in her process of self-awareness: "The protagonist realizes the gap between her natural self and her artificial construct only when she encounters nature. The ecofeminist impact is seen implicit in the novel by the protagonist's return to the natural world. Her association with nature raises her consciousness of victimization of women." Towards the end of the story, in chapter 24, the fusion reaches its climax; firstly, a desultory frog symbolizes the connection: "A frog is there, leopard frog with green spots and gold-rimmed eyes, ancestor. It includes me, it shines, nothing moves but its throat breathing" (233). Later in the chapter, there is a key passage, intentionally written by Atwood in the form of separate paragraphs, that highlights the symbiosis between UP and nature:

The animals have no need for speech, why talk when you are a word

I lean against a tree, I am a tree leaning

I break out again into the bright sun and crumple, head against the ground

I am not an animal or a tree, I am the thing in which the trees and animals move and grow, I am a place (236)

In contrast with this union with the natural environment of the island, there is a sense of rupture with Joe, who works as a masculine archetype for the protagonist: "Everything I value about him seems to be physical: the rest is either unknown, disagreeable or ridiculous" (68). UP's indifference towards him also increases throughout the story; at the beginning of chapter 8 , the tedium is evident:

In the early morning Joe wakes me; his hands at any rate are intelligent, they move over me delicately as a blind man's reading Braille, skilled, moulding me like a vase, they're learning me; ... A phrase comes to me, a joke then but mournful now, someone in a parked car after a highschool dance who said With a paper bag over their head they're all the same. At the time I didn't understand what he meant, but since then I've pondered it. (83)

This feeling of sexual objectification will permeate the mood of the protagonist, who will progressively distance from Joe in emotional terms: "Joe stayed on the wall bench, arms wrapped around his knees in lawn-dwarf position, watching me. Every time I glanced up his eyes would be there, blue as ball point pens or Superman; even with my head turned away I could feel his X-ray vision prying under my skin, a slight prickling sensation as though he was tracing me" (106). Eventually, their relationship will become noticeably deteriorated (up to the 
point that Anna will realize) and Joe's attempts to have sex will be dismissed over threats of pregnancy:

"Don't, I said, he was lowering himself down on me, "I don't want you to."

"What's wrong with you?" he said, angry; then he was pinning me, hands manacles, teeth against my lips, censoring me, he was shoving against me, his body insistent as one side of an argument.

I slid my arm between us, against his throat, windpipe, and pried his head away. "I'll get pregnant," I said, "it's the right time." It was the truth, it stopped him: flesh making more flesh, miracle, that frightens all of them. (188)

Nonetheless, despite their dissimilarities and lack of a deep consistent affective bond, they end up having sexual relations by mutual agreement: he satisfies his carnal desires and she will be able to redeem herself from the loss of her former child: "Nobody must find out or they will do that to me again, strap me to the death machine, emptiness machine, legs in the metal framework, secret knives. This time I won't let them" (210). UP's resolve constitutes an act of both redemption ("I can feel my lost child surfacing within me, forgiving me" [209]) and of self-assertion as a woman, since she will give birth to her child (the "goldfish" [249] in her belly) all by herself in nature, without the interference of a society that has proven patriarchal to her: "This above all, to refuse to be a victim" (249). She has surfaced.

All the same, she is posed a last crux when, after having remained alone in the island for a period of time, Joe comes back in search of her: she must decide whether returning to civilization together with Joe, for whom her love is "useless as a third eye or a possibility" (250), or staying in the place at the risk of isolation in a wild atmosphere. Although there is no certainty that she decides to go with Joe because the end is, once again, intelligently open to ambivalence by Atwood, it seems quite likely that she does: "To trust is to let go. I tense forward, towards the demands and questions, though my feet do not move yet" (251). Should this be the case, we believe that there would be an emphasis on survival: she hopes nothing from neither Joe nor men in general, but she is no less aware that, albeit not strictly necessary, her possibilities of enduring are significantly larger if she is reintegrated into society, in spite of everything it entails. It is a purely rational choice. 


\section{Conclusion}

In light of the current study, it seems indubitable that there is a strong sense of victimization in Margaret Atwood's Surfacing, which concerns both imperialism and gender. In particular, female victimization is quite clearly reflected in the two women characters of the story: Anna and the unnamed protagonist. Yet, whereas the former does not seem to care about her position and ends up suffering abuse from David because of it, the latter - a victim of masculine dominance since childhood-goes through a process of inner discovery that results in her decision to give birth and live isolated in nature, thus constituting an ecofeminist vision of life. At the end, however, it is suggested that she will return with her boyfriend to become a part of the social gear again.

This being the case, the story could be interpreted as a message towards equality: women need men to fully ensure their survival as a human species, but civilized society is too patriarchal a system for them to develop themselves in equal conditions as men. While most of the characters in the book are fit within archetypes -the dominant cynical male, the abused submissive woman, the ruthless American imperialist- to construct the fiction, it is no less true that it is precisely through those roles that Atwood's work becomes relevant from a (eco)feminist point of view. To this approach we must add a whole series of relevant features, such as the richness of the narrator's reflections on her own personal life, her presentation of her family relationships, the unreliable nature of her narration, her process of self-discovery, her contribution to her own victimization or the symbolic language used. All these characteristics have turned Margaret Atwood's Surfacing into a contemporary classic, in which feminism undoubtedly occupies a very significant position.

This article, in an attempt to let the text breathe and speaks (almost) by itself, has very modestly tried to gather some particularly pertinent academic contributions to the topic and to observe how the novel, Surfacing, reflects such notions through the use of language and through the unfolding of events on the part of the author. Rather than corseting the book with a perhaps excessive number of theoretical concepts, we have tried to focus on the novel and to use scholarship as a complement, instead of the other way around. If this paper may thus have any value, it might precisely be the strict consideration of Atwood's writing as such, sometimes forgotten at the expense of other labels which, although indubitably interesting, could push the text -the actual object of analysis-into the background. 


\section{WORKS CITED}

Atwood, Margaret. Surfacing. London: Virago, 2014.

---. Survival: A Thematic Guide to Canadian Literature. Toronto: House of Anansi, 1972.

Bhalla, Ambika. "Ecofeminism in Margaret Atwood's Surfacing." International Journal of Scientific and Research Publications, 2, 2012. $<$ http://www.ijsrp.org/research-paper-1012/ijsrp-p1006.pdf > (last time consulted: $16 / 04 / 18$ )

Denommé, Emily. "Beyond Borders: Nature, Revelation, and Identity in Atwood's Surfacing." Undergraduate Awards, 2016. $<$ https://ir.lib.uwo.ca/cgi/viewcontent.cgi?article $=1014 \&$ context=ungra dawards_2016> (last time consulted: 24/11/18)

Gramsci, Antonio. Selections from the Prison Notebooks of Antonio Gramsci. London: Lawrence \& Wishart Ltd, 2005.

Greimas, Algirdas Julius. "Actants, Actors, and Figures." On Meaning: Selected Writings in Semiotic Theory. Trans. Paul J. Perron and Frank H, Collins. Theory and History of Literature, 38. Minneapolis: U of Minnesota P, 1987. 106-120.

Makhaik, Suman. "Surfacing." Ecofeminism in Margaret Atwood a study of selected novels and short stories. Doctoral thesis from Himachal Pradesh University, 2011.

127-167. $<$ http://shodhganga.inflibnet.ac.in/bitstream/10603/121172/8/08_chapte r\%203.pdf> (last time consulted: 15/04/18)

McWilliams, Ellen. Margaret Atwood and the Female Bildungsroman. Abingdonon-Thames: $\quad$ Routledge, $2017 . \quad$ DOI: https://doi.org/10.4324/9781315249735

Nicolaescu, Cristina. "The Voice of Subaltern in Margaret Atwood's Surfacing: an Anticolonialist Approach to the Novel." Journal of Research in Gender Studies, 5. New York: Addleton Academic Publishers, 2015. 350-355.

Niranjani, Ramya. "Self-Discovery Through Nature in Margaret Atwood's Surfacing." Language in India, 12, 2012. 196-203.

Reshmi, Krishnan. "Ecofeminist Vision: A Study of Margaret's Atwood's Surfacing and The Handmaid's Tale." Critical Essays on Canadian Literature (ed. K. Balachandran). New Delhi: Sarup, 2002. 61-66. 
Sankar \& Soundararajan. "Female Quest for Self-Identity and Women Subjections in Margaret Atwood's Surfacing." CSCanada: Studies in Literature and Language, $\quad 13, \quad 2016 . \quad 40-41$. $<$ http://www.cscanada.net/index.php/sll/article/view/8892> (last time consulted: $24 / 11 / 18$ )

Tolan, Fiona. "Surfacing: Origins and Identity." Margaret Atwood: Feminism and Fiction. Amsterdam: Rodopi, 2007. 35-58. DOI: https://doi.org/10.1163/9789401204545 004

Willens, Michele. "The Mixed Results of Male Authors Writing Female Characters." The Atlantic, 2013. The Atlantic Monthly Group. $<$ https://www.theatlantic.com/sexes/archive/2013/03/the-mixed-resultsof-male-authors-writing-female-characters/273641/> (last time consulted: 16/04/18) 